КУЛЬТУРОЛОГІЧНІ РОЗВІДКИ

DOI: https://doi.org/10.51209/platform.2.4.2021.164-188

УДК 791.63.(477):791.037.7(450.)

Галина Петрівна ПОГРЕБНЯК,

доктор мистецтвознавства, доцент, Національна академія керівних кадрів

культури і мистецтв,

Київ, Україна,

e-mail: galina.pogrebniak@gmail.com,

ORCID: 0000-0002-8846-4939

\title{
ФУНКЦОНУВАННЯ РЕЖИСЕРСЬКИХ МОДЕЛЕЙ АВТОРСЬКОГО КІНО В КУЛЬТУРНО-МИСТЕЦЬКОМУ ПРОСТОРІ МІЖНАРОДНИХ КІНОФЕСТИВАЛІВ
}

\begin{abstract}
Анотація. У статті розглядаються міжнародні кінофестивалі, які мають значний соціально-економічний потенціал і $є$ потужною складовою культурно-мистецького життя. Показано, що прикметою нинішніх міжнародних кінофестивалів є поновлення тенденції гострого критичного погляду на світ, а також посилення авторського начала, що відображає життєвий досвід, характер світосприйняття та світовідтворення режисера-постановника - творця власної кіномоделі. Обгрунтовано спроможність ведення міжкультурного діалогу засобами авторського кіно. Визначається місце українських авторських фільмів у міжнародному фестивальному просторі. Простежується процес входження вітчизняного авторського кінематографа в міжнародний фестивальний простір 3 метою розповсюдження інформації про системні зміни в законодавстві щодо підтримки кіноіндустрії; маніфестації специфічної художньо-естетичної та морально-етичної спрямованості українського кіномистецтва; демонстрації рівня професійної підготовки кінематографістів; представлення фільмової продукції 164
\end{abstract}


представникам міжнародної дистриб'юції; налагодження кроскультурних зв'язків; зміцнення кінематографічного іміджу України. Встановлено, що нагородження українських кіномитців призами престижних міжнародних кінофестивалів свідчить про спроможність вітчизняних майстрів, утверджуючи національні пріоритети та висвітлюючи значимі загальнолюдські проблеми, спілкуватись із міжнародною спільнотою зрозумілою кінематографічною мовою.

Доведено, що успіх українських фільмів на міжнародних кінофорумах демонструє затребуваність вітчизняного авторського кіно в сучасному культурному просторі, поступове формування брендів «українське кіно», «українське авторське кіно», створення в потенційних партнерів упізнаваного позитивного образу України. Доведено, що значний успіх Фестивалів українського кіно в різних країнах світу свідчить про те, що вітчизняні авторські фільми виступають потужним каналом комунікації, складником культурної дипломатії, дієвим інструментом культурної політики України, сприяючи творенню iï іміджу як кінематографічної країни та інтеграції у світовий культурний простір.

Ключові слова: автор-режисер, авторський кінематограф, авторська режисерська модель, інтелектуальне кіно, кінофестиваль, кроскультурні відносини

Вступ. Близько 90 років (від часу створення у 1932 р. найстарішого нині міжнародного кіноогляду у Венеції) міжнародні кінофестивалі, виступаючи засобом поширення інформації щодо конкретних подій у тій чи іншій країні (коли за кілька днів можна побачити панораму життя в різних країнах світу), слугують підтвердженням того, що кожна держава сама обирає та презентує певну функціональну значущість того, що відбувається в межах ії культурної політики як сукупності принципів, механізмів, заходів, спрямованих на створення умов для повноцінного культурного розвитку суспільства на максимально можливе забезпечення основної ролі культури в розвитку самореалізації сутнісних сил людини, гуманізацію 
суспільства, забезпечення культурних потреб громадян, а ще тієї специфічної царини публічного політичного процесу, що має віддзеркалювати основні принципи й цінності в культурному житті на міждержавному, національному та місцевому рівнях [8, c. 203].

Нагадаємо, що вказаний вище кіноогляд у Венеції відбувся в межах XVIII Венеційського бієнале мистецтв (художньої виставки, що заснована 1895 р. та проходить раз на два роки - «Esposizione Internazionale d'Arte Cinematografica») 3 метою як широкої популяризації італійських кінотворів (презентованих із усіх регіонів країни в одному місці), так i розвитку туристичної індустрії та готельного бізнесу, крім того, захід «мав виразні ознаки геополітичного проекту, про що свідчила потужна підтримка, надана йому фашистським урядом Італії» [12, с. 97].

Тогочасний Венеційський фестиваль (який, за іншою версією, зініціював генеральний секретар бієнале Антоніо Маріані) відкрили на острові Лідо 6 серпня 1932 р фільмом режисера Рубена Мамуляна «Доктор Джекіл і містер Хайд». Безперечно, означений кінофорум відбувся за підтримки впливових осіб, передусім, бізнесмена й політика, графа Джузеппе Вольпі ді Місурата, який був ще і його першим президентом, а серед гостей свята кіно - переважно аристократичної публіки - були здебільшого друзі та приятелі графа, для яких влаштували розкішні бали, костюмовані прийоми, маскаради тощо. Показово, що серед кінотворів, представлених на першому Венеційському кінофестивалі (що нині є одним з провідних кінофорумів світового рівня), був і фільм українського режисера О. Довженка «Земля», якому надали свідоцтво про участь, оскільки на той час на такому заході ще не присуджували нагород.

Нині твори вітчизняних кінорежисерів, що наразі лише формують українську модель авторського кіно, активно долучаються до міжкультурного простору кінофорумів, адже стрімкий розвиток міжнародного фестивального руху передусім пов'язаний із тим фактом, що досить велика кількість фільмів 
(зокрема авторських), вироблених у всьому світі, які становлять певну художньо-мистецьку цінність, не завжди економічно рентабельні й не потрапляють у комерційний прокат, тоді як саме кінофестиваль i стає взаємовигідною (принаймні кінематографістам і публіці) нагодою продемонструвати й подивитись такий кінопродукт.

Постановка проблеми. Сьогодні, виступаючи одним iз найпродуктивніших способів презентації як особистості постановника, так i просування кінопродукції, міжнародні кінофоруми є унікальною можливістю показати режисерові свої «фільми широкому колу» як публіки, так і кінематографістів, що прискіпливо оцінюють рівень (як творчий, так i технологічний) фаховості митця, концептуальність його ідей, вартісність філософських меседжів, морально-етичних, естетичних, світоглядних установок. Адже «отримані призи, що для багатьох $\epsilon$ просто сатисфакцією, задоволенням певних амбіцій, насправді» спроможні рухати митця далі [15, с. 21]. Таку можливість намагаються використати й українські кінематографісти, презентуючи в міжкультурному просторі передусім авторські фільми і роблячи досить успішні спроби сформувати національний бренд «українське кіно», «українське авторське кіно», якість якого як україностверджувального поступово зростає i дозволяє кіномитцям повноправно вливатись у світовий кінопроцес.

Аналіз останніх досліджень і публікацій. Фестивальна діяльності, роль кінооглядів у налагодженні кроскультурних зв'язків, а також участь у кінофорумах режисерів-авторів (як митчів з індивідуально-особистісним баченням і відтворенням екранними засобами картини світу, прагненням до новаторства форми, підвищеної складності кінотексту, намаганням поглибити зміст образів, зосередитись на стилістичних прийомах, здатністю вести оповідь неординарною кіномовою) висвітлюється в значній кількості досліджень, зокрема в роботах таких теоретиків і практиків екранних мистецтв, як: Л. Бабушка, К. Білокінь, С. Васильєв, А. Гурков, С. Дейнека, Я. Грановська, Д. Зубенко, П. Жессаті, 
Л. Журавльова,

А. Кедбері, О. Кирилова,

Т. Клерк, А. Крисальна, О. Овчарук, Б. Периль, О. Першко, А. Плахов, О. Роднянський ін.

Відзначимо, що історико-культурологічні та художньоестетичні аспекти кінофестивалю як чітко налагодженої системи творчих змагань та презентації в ній національного авторського кіно проаналізовано в дослідженнях Я. Грановської «Кінофестиваль як соціокультурний феномен», «Кінофестиваль як кроскультурний проєкт». Своєю чергою О. Овчарук у роботі «Культурна дипломатія: теоретичний та прикладний аспект» переконливо доводить, що кінофестивалі виступають важливим складником «культурної дипломатії», котра $\epsilon$ «одним iз визначальних факторів, що сприяє забезпеченню державних інтересів», 3 одного боку, будучи продуктом, 3 іншого своєрідним «механізмом забезпечення функціонування зовнішньополітичних інструментів, оскільки, іiі не просто застосовують на всіх рівнях - вона має унікальну здатність формувати думку світової громадськості щодо культури певної держави, iї національних культурних традицій i загалом культурних стратегій розвитку» $[13$, с. 67]. У статті «Кінофестиваль в контексті функціональності мистецтва» T. Кохан виявляе специфіку фестивального руху як мистецького явища та визначає особливе місце українських, зокрема, авторських фільмів. Тоді як особливості міжнародного кінофоруму як організаційно-художньої форми демонстрації, оцінки та розгортання творчих пошуків сучасного кінематографа, його основні форми, напрями i принци функціонування Б. Периль окреслює в праці «Фестивальна практика: досвід case-study».

Метою статті $\epsilon$ узагальнення здобутків українських режисерів-авторів у міжнародному фестивальному просторі та визначення міжкультурного потенціалу фільмів, що представляють українську модель авторського кіно.

Виклад основного матеріалу. У, так би мовити, віковій категорії кінофестивалів Каннський (нині найбільший у світі кінофестиваль) посідає третє місце, адже точкою відліку 
історії цього кінофоруму служить 1936 р., коли представники демократичних сил західноєвропейських країн, відвідавши Венеціанський кіноогляд, були обурені впливом фашистських урядів Італії та Німеччини як на конкурсний добір фільмів, так i рішення журі. То ж, міністр освіти Франції Жан Зай зініціював проведення альтернативного міжнародного кінофестивалю в Каннах, підготовка якого розтягнулась майже на три роки, а прем'єра була призначена (за головуванням у журі визначного кіновинахідника Луї Люм'єра) на 1 вересня 1939 р. Проте фестиваль, метою якого було сприяння розвитку кіномистецтва й духу співробітництва між країнами-кіновиробниками (і який мав би тривати ще 20 днів) попри гучне відкриття, так і не відбувся - на заваді тому стала Друга Світова війна. На повну силу фестиваль став функціонувати лише сім років потому, відкрившись 20 вересня 1946 р. документальним радянським фільмом «Берлін» Ю. Райзмана, проте ця подія відбувалась ще не в Палаці фестивалів (який буде введений в екслуатацію тільки 1949 р.), а в приміщенні одного з розкішних каннських казино. Прикметно, що відновленню кінофоруму в Каннах (попри складну економічну ситуацію й кризу у французькій кіноіндустрії) сприяла, в першу чергу, ініціатива самого приморського міста, мотивована прагненням «розвиватися як курорт», чому сприяв би приїзд знаменитостей із усього світу, необхідністю переконати, що «можна відпочивати не лише в Сен-Тропе та Ніцці» [11].

Серед кіноробіт, демонстрованих на тодішньому післявоєнному міжнародному кінофорумі в Каннах, були фільми «Рим, відкрите місто» Р. Росселліні, «Погана слава» А. Хічкока, а також фільми радянського виробництва «Великий перелом» Ф. Ермлера (що здобув головний приз), «Людина 217» М. Ромма, «Кам'яна квітка» О. Птушка, «Салют, Москва» С. Юткевича. Примітно, що регулярними кінофоруми у Каннах стають тільки 31952 р., коли час проведення їх зміщується 3 осені на весну, що уможливлює показ більшої кількості кінострічок, раніше, ніж вони опиняються на інших кінофестивалях, а ще слугує своєрідним «розігрівом» 
туристичного сезону. То ж, відмітимо, що за досить короткий відрізок часу Каннський фестиваль став однією 3 найважливіших культурних подій Свропи, а згодом - i світу i, являючись найбільшим кінофорумом світового рівня, й донині викликає жвавий інтерес основних представників кінобізнесу та журналістів із різних країн.

Нині стрімкий розвиток міжнародного фестивального руху, передусім, пов'язаний із тим фактом, що досить велика кількість фільмів (зокрема авторських), вироблених у всьому світі, що представляють певну художньо-мистецьку цінність, не завжди економічно рентабельні й не потрапляють у комерційний прокат - тоді як кінофестиваль саме і стає взаємовигідною (принаймні кінематографістам i публіці) нагодою продемонструвати i подивитись такий кінематографічний продукт. При цьому, на переконання А. Плахова, фестивалі дійсно тривалий час існували у формі доволі елітарної інституції, проте вже наприкінці XX ст. стали досить швидко змінюватись. Так, приміром, з'явився кінофорум у Торонто, орієнтований як на широку міську аудиторію, так $\mathrm{i}$ на ринок, тоді як Берлінський і порівняно новий Роттердамський також переорієнтувались на міського глядача. Своєю чергою навіть виключно професійний Каннський кінофорум (що дав старт кращим представникам авторського кіно П. Альмадовару, М. Антоніоні, А. Вайді, К. Зануссі, О. Іоселіані, Т. Кетано I. та Д. Коенам, Д. Кроненбергу, Е. Кустуріці, Д. Лінчу, Р. Поланскі, А. Рене, М. Скорсезе, К. Тарантіно, А. Тарковському, Л. фон Трієру, Ф. Трюффо, Ф. Фелліні, ін.) почав демонструвати комерційну кінопродукцію, щоб створити ажіотаж, привабити публіку, підняти рейтинг. При цьому, зі слів колишнього президента Жиля Жакоба (що, очолюючи престижний фільмовий огляд з 1976 р., понад тридцяти років, зумів провести його крізь складний перехідний час «від модернізму до постмодернізму і його згасання») вже наприкінці XX - на початку XXI ст. на кінофестиваль стали запрошувати Шерон Стоун і Катрін Деньов, щоб завітала публіка, яка би заразом подивилась і роботи Мануеля де Олівейри чи то 
Олександра Сокурова, адже масова культура давно стала частиною фестивального організму, серцем якого первісно було мистецтво [14]. В одному 3 інтерв'ю Ж. Жакоб (серед нововведень якого на Каннському кінофорумі з'явилась і друга за значимістю після основного конкурсу програма «Особливий погляд»- «Un Certain Regard», що гарантує призерові підтримку у французькому кінопрокаті, i програма підтримки короткометражних (до 60 хвилин) робіт молодих авторів «Cinefondation», 3 метою стимулювання підготовки молодого покоління кінематографістів), зізнався, що для нього (попри розбіжність думок щодо Канну як столиці гламуру) кіноавтор, постаючи художником, режисером, творцем, завжди залишався головним на кіноогляді. У зв'язку з цим і виникла ідея до 60ліття вказаного кінофестивалю 2007 р. віддати шану визначним режисерам-авторам, що в різні часи брали в ньому участь, надавши можливість кожному зняти короткий фільм, який би згодом був демонстрований на кінофорумі у присутності усіх кіноавторів. Виступивши продюсером проекту, Жакоб (діяльність якого. як і час, минули наприкінці XX ст., коли остаточно пішов у небуття класичний кінематограф [14]), разом 336 режисерами (серед них: Вім Ведерс, Жан-П'єр та Люк Дардени, Алехандро Гонсалес Іньярриту, Акі Каурісмякі, Такесі Кетано, Ітан та Джоел Коени, Девід Кроненберг, Клод Лелуш, Девід Лінч, Кен Лоуч, Мануель де Олівейра, Роман Поланскі, Ларс Фон Трієр, ін.), що погодились взяти участь у присвяченому пам'яті Федеріко Фелліні альманаху «У кожного своє кіно, або Як завмирає серце, коли гасне світло і починається сеанс», довго шукали тему, яка б об'єднала різних авторів. Такою стала тема кінотеатру, а, точніше, напівзруйнованого й напівпорожнього кінозалу (як своєрідного образу тривоги за долю кіно як мистецтва), адже саме в такому стані нині знаходяться переглядові зали, в яких демонструються авторські фільми [16].

Дозволимо собі нагадати, що авторським кінематографом називатимемо такий, в якому репрезентована постать режисера-постановника, неповторна індивідуальність зі 
своєю філософією, світоглядом, суб'єктивною системою сприйняття, оцінки, зображення картини світу й образу людини в ній; особистість, здатна представити власну кінематографічну світомодель; спонукати глядача, проникаючи в загальнолюдські проблеми, переінакшувати своє ставлення до реальності, робити спроби трансформувати навколишню дійсність. Водночас авторський кінематограф $\epsilon$ конгломератом розмаїтих $\mathrm{y}$ філософському, художньо-естетичному, морально-етичному, національно-етнічному розумінні моделей, кожна 3 яких $\epsilon$ певним образом світу, аналогом реальних або ймовірних фактів, фіксує елементи складних явищ і процесів та сформувалась у різний час та під впливом несхожих обставин. Важливо відмітити, що авторське кіно, на відміну від комерційного (жанрового), не має розважальної мети, його основним завданням є зміна уявлення та ставлення людини до дійсності, формування спроможності бачення суспільнозначимих проблем та спонукання до прагнення змінити реальність навколо себе. Разом $з$ тим, ведучи мову про кінематографічну світомодель, зазначимо, що фільм як модель проходить уявну стадію задуму і iii вербальне втілення в кіносценарії і постає матеріально реалізованою кінематографічною системою, яка, відображаючи чи відтворюючи в певному сенсі об'єкт мистецтвознавчого дослідження, здатна заміщати його так, що вивчення моделі дає нову інформацію про досліджуваний мистецький об'єкт. Своєю чергою авторська (режисерська) кінематографічна світомодель - це засіб, форма пізнання світу режисером, відтворення ним картини світу (3 акцентуванням на його індивідуально-особистісному сприйнятті) за допомогою кіномови, основним структурним елементом якої $є$ кадр. У режисерській моделі авторського кіно суб'єктом моделювання виступає особистість режисера, який демонструє своє світовідношення у художньо-образній формі, за допомогою екранної мови, основним культуротворчим елементом якої $\epsilon$ кадр. При цьому, кінодійсність підкорюється задуму автора, трансформується і набуває форм, відмінних від життєподібних. 
Парадоксально, але нинішній, наразі кризовий, стан українського кіновиробництва ((попри деякі незначні (як для такої затратної галузі), позитивні зрушення, починаючи 3 2017 р.)), вщент зруйнований кінопрокат - усе це сприяло не лише прориву вітчизняних кіноавторів у міжнародний фестивальний простір, а з'яви на престижних кінофорумах класу «А», що дало можливість для «арт-кіна бути оціненим, а для його режисерів - працювати далі, отримуючи для цього не тільки фінансові, а й виробничі, оперативні нагоди» [15, с. 21].

Розмірковуючи над проблемою презентаціії режисерських моделей українського авторського кіно в міжнарожному просторі й здатності українських митців до міжкультурного діалогу, відзначимо, що пишатися, особливо в останні десятиріччя, є чим і ким, зокрема кінороботами (що й складають авторську кіномодель) Сергія Лозниці.

У фільмі С. Лозниці «Майдан» (вже сама назва якого красномовно вказує не тільки на місце, але й час дії) світова прем'єра якого (разом із фільмом М. Слабошпицького «Плем'я») відбулась у травні 2014 р. на 67-му міжнародному фестивалі у Канні - «головним героєм стає збірний образ українського народу, який змінив хід історії» [4]. Характерно, що С. Лозниця, приїхавши до Києва у пошуку локацій для майбутнього проекту «Бабин Яр», випадково опинився у вирі революційних подій на Майдані. То ж, надовго відклавши роботу над згаданим проектом i залишаючись вірним документалістиці, він прийняв рішення фільмувати (у формі епічного оповідання) реальні події (стежачи за якими не міг передбачити, чим усе може закінчитись, а звідси й двогодинна тривалість), триматись осторонь яких для режисера-автора суперечило його громадянській позиції. Хоч на думку української мистецтвознавиці О. Волошенюк, складається враження, що автор від самого «початку знав, що він буде знімати і яким чином він буде знімати» [2]. Слідуючи, зі слів самого постановника, «за народом», «його кращими представниками», він зрозумів, що йому цікаві конкретні люди, які знаходилися у вирі 90-денних подій (ключового перелому в 
яких на екрані свідомо не показано), їх дії, вчинки, то ж, і був обраний спосіб тривалого спостереження «за всіма і всім», що допоміг авторові «триматися відстороненим». Ймовірно, тому, дотримуючись основних засад монтажного кінематографу у створенні фундаментальної за формою кінооповіді 3 іï багатоплановою дією, режисерові довелось ставити статичну камеру (чим неодноразово дорікали митцеві) таким чином, щоби «вона фіксувала багатофігурні композиції, в яких - на кількох планах і рівнях - діють маси людей», а народ виступає головним героєм (що розширювало погляд на події) у ретельно створених закінчених гармонійних (не розімкнутих, не розірваних) композиціях [9].

Відомо, що міжнародні кінофоруми, виступаючи засобом розповсюдження інформації щодо конкретних подій у тій чи іншій країні, викликають значний інтерес громадськості, тоді як кожна країна сама наголошує на функціональній значущості того, що відбувається. Таким виявився інтерес як глядачів, так і представників світових 3MI, до подій на Майдані (a, отже, й стрічок, що висвітлювали їх) в Україні 2014 р. на Каннському кінофестивалі, де, окрім фільму С. Лозниці, була презентована ще низка картин на дану тематику (як то «Небесна сотня», «Чорна книга Майдану», «Київ. Війна на Інститутській», «Жінки Майдану», ін.), що, сприйняті публікою на високому емоційному рівні (як, власне, емоційним «Майдан» був і для самого режисера), викликали справжній ажіотаж, що змусило організаторів Українського павільйому розширювати його межі (об'єднавшись 3 Азербайджанським), щоб розмістити всіх бажаючих. Тоді як $з$ ініціативи Жерома Паяра, очільника «Le Marche du film du Festival de Cannes», того року для українських кінематографістів «вперше в практиці Каннського кіноринку сума оренди» павільйону була зменшена 3 17,6 тисяч євро вдвічі [9].

Створивши фільм «Майдан» у найкоротші терміни за фінансової підтримки нідерладської компанії «Atoms \& Void», С. Лозниця презентував кінороботу не лише в офіційній програмі Каннського кінофоруму, а й на кінофестивалі 
документального кіно «Astra Film Sibiu» IFF в Румунії (де, окрім здобуття Гран-прі, в спеціальній програмі «Фокус фестивалю» було демонстровано ще три ранні стрічки режисера), МКФ у Срусалимі, Лондоні, IX Міжнародному кінофестивалі 3 прав людини у Нюрнберзі («Nuremberg International Human Rights Film Festival») (отримавши головну нагороду у номінації «Найкращий фільм»), у Гельсінкі, БуеносАйресі, Лісабоні, Батумі. Така висока оцінка вказаного фільму видається нам не випадковою, адже сучасне неігрове українське кіно не з'явилось нізвідки, а неухильно розвивало кращі традиції та творчі здобутки класичного вітчизняного кінематографу, що завжди високо поціновувався у світі. Варто згадати хоча би той, по суті, визначний факт, що кінострічка Дзиги Вертова «Людина 3 кіноапаратом», фільмована далекого 1929 р., була названа першою в оприлюдненому 2014 р. Британським кіноінститутом чи не найавторитетнішому кінорейтингу, тоді як, за версією впливового британського часопису «Sight \& Sound» (куди номінувалося більше 1000 кіноробіт, створених протягом усієї історії кіно), саме дозвукова українська картина була названа кращою в неігровому секторі [17].

Надзвичайно важливо, що показ «Майдану» (прем'єра в Україні якого відбулась на Одеському МКФ), стався не лише за кордоном (як то у Польщі, Нідерландах, США), але й (у дистриб'юції компанії «Arthouse Traffic») у сорока дев'яти кінозалах України, ставши чи не першим за багато років вітчиняним ігровим фільмом, що викликав значний інтерес публіки й широко демонструвався в прокаті, адже, зрештою, фільм був створений передусім для українського глядача.

Про інтерес до українського авторського кіно, i, зокрема, до робіт С. Лозниці, свідчить той факт, що і наступний фільм режисера, «Лагідна» (кіноадаптація одноіменного оповідання Ф. Достоєвського), створений за пітримки від фонду «Eurimages», у копродукції Франції, Німеччини, Нідерландів, Латвії та Литви (без офіційної державної підтримки з боку України, проте, за фінансового сприяння вітчизняної компанії 
«Solar Media Entertainment» - SME ), тим не менш, був включений в офіційну конкурсну програму 70-го Каннського кінофоруму (де й відбулась його прем'єра 2017 р.) як робота саме українського автора-режисера. Примітно, як для авторського почерку, що ніби то «звичайну» притчеву історію про приниження та насильство, про викриття найогидніших людських якостей, митець зумів розповісти, застосовуючи таку ж, на перший погляд, «звичайну» «реалістичну», майже документальну за стилем, візуальну мову, що надало оповіді жахливого відчуття повсякденної випадковості й присутності зла, шокуючої правди у толерантності до брехні, байдужості, злочинного мовчання [18].

Створивши авторський фільм не для широкого глядача, що, проживши насичену фестивальну історію, увійшов за версією авторитетного британського видання «Тhe Guardian» до списку тридцяти восьми кращих фільмів 2018 р., був включений до т. зв. лонг-листа Свропейської кіноакадемії («European Film Academy»), потрапив до номінантів на премію АзіатськоТихоокеанської кіноакадемії («Asia Pacific Screen Awards»), став володарем української національної кінопремії «Золота дзига» та, попри неоднозначність в оцінках критиків, знайшов своїх шанувальників серед публіки (зокрема, й демонстрований у форматі домашнього відео завдяки бельгійській компанії «Imagine», що випустила фільм у DVD-форматі та VOD на платформі «іTunes»), C. Лозниця довів, передусім, на міжнародному рівні, потужність і живучість традицій режисерської школи українського авторського кіно. Ймовірно, саме тому його наступний фільм «Донбас» про воєнні події на Сході країни (як і попередній фільм, підтриманий фондом «Eurimages» і створений за державної підтримки у співпраці 3 кінематографістами Румунії, Франції, Нідерландів та Німеччини, де виробником від України виступила компанія «Arthouse Traffic») був включений до офіційного конкурсу другої за значимістю програми «Особливий погляд» наступного 71-го Каннського кіноогляду 2018 р. і, здається, не випадково 
демонстрований саме 9 травня, отримав нагороду в номінації «За найкращу режисуру».

На наше переконання, той міжнародний (та власне й внутрідержавний) скандал, який намагався дещо передчасно вчинити на початку XXI ст. Ю. Іллєнко, продукуючи фільм «Молитва за гетьмана Мазепу» (презентованого, нагадаємо, на Берлінському МКФ) уповні вдалося реалізувати С. Лозниці 3 «Донбасом». Адже такого шаленого шквалу абсолютно полярних відгуків про кінострічку (подану Українським Оскарівським Комітетом як національного претендента від України номінантом на здобуття премії Американської кіноакадемії «Оскар» у категорії «Найкращий фільм іноземною мовою») представників як іноземних, так і українських видань, репрезентантів російської дипломатії (що саме і демонструє жвавий інтерес до кінороботи) режисерові годі було й очікувати. Адже, як вважає А. Долін, дана картина саме й присвячена «масмедіа, соціальним мережам та іншим посередникам, які обретають війну на шоу», що само по собі робить «Донбас» неможливим парадоксом, оскільки картина - про те, що не може і не повинно перетворюватися на «просто кіно» [5].

Звинувачення постановника фільму, який, сказати б, остаточно вийшов у площину ігрового кіно, хоч і почерпнув матеріал 3 хронікально-документальних роликів, демонстрованих на сепаратистських телеканалах (в «антихудожності», «фрагментарності», «хаотичності», «фейковості», «невиправданій гротесковості», «умовності», «надмірній відвертості», «некомпліментарності», «однозначності й водночас недосказаності у відображеннні воєнних подій», «спрощеності», «русофобії, «розпалюванні міжнаціональної ворожнечі», «нейтральній документальності» й, разом 3 тим, «гіперреалістичності», «антигуманності», «жорстокості», «незатишності», «безіменності, некрасивості й ряженості героїв, схожих на біомасу», та навіть неправомірному використанні як непрофесійних, так i професійних виконавців (на кшталт коміків трупи «Маски-шоу» тощо), тільки розпалили інтерес до «Донбасу» організаторів 
низки міжнародних кінофорумів й увінчали режисера-автора нагородами. Отримавши Гран-прі на XV, організованому Інститутом культури і мистецтв, Фестивалі європейського кіно в іспанській Севільї («Festival de Cine Europeo de Sevilla»); здобувши головний приз - «Золотий павич» за найкращий фільм на Індійському міжнародному кінофорумі в Гоа («International Film Festival of India»), одному з найголовніших акредитованих Міжнародною федерацією асоціацій кінопродюсерів (FIAPF) кінооглядів Азії; виборовши спеціальну відзнаку журі за кращу режисуру - «Срібна піраміда» Каїрського МКФ («Сairo International Film Festival»); демонстрований на МКФ у Карлових Варах, Мюнхені, Срусалимі, Мельбурні, Торонто фільм, зрештою, дістався й IX Одеського кінофоруму, де й відбулась його українська прем'єра як призера міжнародних кінооглядів у програмі «Фестиваль фестивалів».

Проте, у контексті сказаного 3 прикрістю слід констатувати, що увінчана численними нагородами стрічка «Донбас» (зокрема й Національною кінопремією «Золота дзига» та Національною премією кінокритиків «Кіноколо») у візуальному авторстві О. Муту, стрічка, що здобула широкий міжнародний розголос, мала досить широку закордонну дистриб'юцію, в Україні, як це не парадоксально, вийшла в обмежений прокат в ОДНОМУ київському кінотеатрі «Жовтень», у результаті чого на рахунки «Держкіно» було перераховано лише 1 477,04 гривень при затраченій державою сумі фінансування 16736300 гривень. Пізніше зацікавленим глядачам (хоча лише в кількох українських містах - Дніпрі, Львові, Маріуполі, Одесі, Харкові, Чернівцях) таки вдалось побачити стрічку, озвучену російською мовою та ще й 3 англійськими субтитрами в межах фестивалю «Нове Німецьке кіно», організованого компанією «Arthouse Traffic». Озвучення українською мовою також викликало низку суперечок навколо фільму, оскільки відповідно до законодавчих норм створення копродукції (де є частка державного фінансування), фільмовий продукт відповідно набуває національного статусу, що регламентовано Статтею 3 (абзац шістнадцятий із змінами, 
внесеними згідноіз Законом N 1909-VI (1909-17) від 18 лютого 2010 р.), коли таким вважається фільм, створений суб'єктами кінематографії України, виробництво якого здійснено в Україні, та авторське право чи право власності на який цілком або частково належить суб' єктам кінематографії України, а також основна (базова) версія мовної частини звукового ряду якого створена украйнською мовою. А крім того, за мотивованим рішенням Ради 3 державної підтримки кінематографії, на підставі звернення суб'єкта кінематографії, якщо це виправдано художнім, творчим задумом авторів фільму, в основній (базовій) версії національного фільму (крім дитячих та анімаційних фільмів) допускається використання інших мов в обсязі, що не може перевищувати десять відсотків загальної тривалості всіх реплік учасників фільму. Під час демонстрування національного фільму в Україні такі репліки мають бути дубльовані або субтитровані українською мовою» [7]. То ж, озвучений відповідно до законодавства України державною мовою (так би мовити, «для годиться») фільм, який сам режисер назвав «трагіфарсом», створеним за принципом шокової «кінотерапії» (у чомусь запозиченої у у стрічці Л. Бунюеля «Привид свободи»), в прокаті все одно демонструвався російською, ніби підтверджуючи свій трагіфарсовий статус. В одному з інтерв'ю С. Лозниця (який все ж позиціонується, принаймні в кіносвіті, як український режисер) назвав український дубляж «Донбасу» досить дивним, оскільки всі в Україні чудово розуміють російську мову, то ж, він начебто і не заперечує звучання української та й будь-якої іншої мови, що у репліках передає мелодику голосу. Як виявляється, на переконання автора, демонстрація в Україні національного фільму іноземною мовою не $є$ проблемою, оскільки, на тій території, про яку йдеться, дійсно розмовляють російською (що доступна всім мешканцям нашої країни), якою i знімалась стрічка [6]. Розмисли постановника підтримує I. Грабович, який переконаний, що озвучення фільму українською мовою надає фільмові зайвих елементів відчуження й виглядає «невдалим» із погляду цілковитої руйнації первісного звуку в його шумах, синхронних 
репліках. У статті «Все буде Донбас?» критик вказує, що «майже цілковита відсутність шумів (за винятком надто гучних звуків на кшталт вибухів) робить картину фактично стерильною у звуковому плані», так само, як і «почищені» діалоги, з яких або прибрано майже всю лайку або замінено м'якішими висловами, що дає своєрідний ефект стерильності й не лише шкодить фільмові, а й оголює моторошну соціальну механіку, яка стоїть за всім цим. Автор переконаний, що коли йдеться про вербальність «Донбасу», основна ії сутність знаходиться «не у словах, які в картині всуціль брехливі, а в діях, які ті слова прикривають, тоді як наявність оригінальних слів у всій їхній колоритній первісності роблять стрічку смішнішою, ніж вона того потребує». Зрештою І. Грабович доходить висновку, що «показана реальність страшна, як не крути, неповторні словесні інтонації тільки ії пом'якшують, певним чином примиряють із побаченим» [3].

То ж, коли йдеться про демонстрацію визнаного в світі національного фільму в системі кіноіндустрії Україні, слід дослухатись до думки О. Роднянського, який вважає, що індустрія кіно - це те, що функціонує самостійно, поза допомогою держави, яка має виступати найважливішим законодавчим регулятором, стимулом розвитку, але не більше. На переконання кінопідприємця, кошти потрібно видавати не обов'язково на кіновиробництво. Краще, аби це були гранти на створення системи прокату, на стимулювання кінотеатрів, що «фокусуються не на атракціонному кіно, а створюють паралельну систему прокату якісного незалежного кіно», компенсуючи витрати, які понесли б кінотеатри, які не демонструють блокбастери Голлівуду [1].

Висновки. Узагальнюючи здобутки українських режисерів у фестивальному русі (на прикладі фільмів Сергія Лозниці, що складають його режисерську авторську модель), ми обгрунтовуємо спроможність ведення міжкультурного діалогу засобами авторського кіно. Нами встановлено, що нагородження українських кіномитців призами престижних кінофестивалів (зокрема у Каннах) свідчить про спроможність вітчизняних 
майстрів, утверджуючи національні пріоритети та висвітлюючи значимі загальнолюдські проблеми, спілкуватись із міжнародною спільнотою зрозумілою кінематографічною мовою. Ми обгрунтовуємо та доводимо, що успіх українських фільмів на міжнародних кінофорумах демонструє затребуваність авторського кіно в сучасному міжкультурному просторі та є свідченням формування брендів «українське кіно», «українське авторське кіно», створення в потенційних партнерів пізнаваного позитивного образу України.

\section{Список використаної літератури:}

1. Александр Роднянский: «Работа продюсера - это брак с автором». URL: https://mediananny.com/raznoe/2300316/

2. Волошенюк О. Кінорепрезентації Майдану: реабілітація фізичних

реальностей. URL: $\quad$ http://medialiteracy.org.ua/kinoreprezentatsiyi-majdanureabilitatsiya-fizychnyh-realnostej/

3. Грабович I. Все буде Донбас?

URL: https://detector.media/kritika/article/141309/2018-09-27/

4. Документальна стрічка «Майдан» Сергія Лозниці виходить в український прокат у липні. URL: https://www.tv.zt.ua/index.php/ru/302-dajdzhest-novostej-tvrynka-1-16-marta-284

5. Долин А. «Донбасс» Сергея Лозницы: театр военных действий и абсурда. На Каннском фестивале показали фильм о жизни в ДНР и ЛНР

URL: https://meduza.io/feature/2018/05/09/donbass-sergeyaloznitsy-teatr-voennyh-deystviy-i-absurda

6. Донбас - місце, де розпадається ритуал. Сергій Лозниця про свою нову картину і війну на Сході

URL: $\quad$ https://nv.ua/radio/forperspectiveshow/donbas-mistse-derozpadajetsja-ritual-serhij-loznitsja-pro-svoju-novu-kartinu-i-vijnuna-skhodi-2506960.html

7. Закон України «Про кінематографію».

URL: $\quad$ https://zakon.rada.gov.ua/laws/show/9/98$\%$ D0\%B2\%D1\%80\#Text 
8. Карлова В.В. Культурна політика. Філософія: словникдовідник. За ред.: І. Ф. Надольного, І. I. Пилипенка, В. Г. Чернеця. Київ: НАКККіМ, 2011. Сc. 203-204.

9. Лозница С. «Майдан»: «Думать, что такой фильм может изменить ситуацию - это иллюзия

URL: https://platfor.ma/magazine/text-sq/experience/sergei-loznitsa/

10. «Майдан» Сергея Лозницы: Канны - Одесса - мир.

URL: http://www.mk.mk.ua/rubric/culture/2014/07/19/15703/

11. Макаров Ю. Творити український бренд.

URL: https://tyzhden.ua/Publication/2505

12. Новікова Л. Політичний аспект діяльності міжнародних кінофестивалів. Сучасні дослідження в галузі культури $\mathrm{i}$ мистецтва: зб. матеріалів V Міжн. наук.-практич. конф., 30.04.2020 р. Київ, 2020. Сс. 97-99.

13. Овчарук О. Культурна дипломатія: теоретичний та прикладний аспект. Культурні та мистецькі студії XXI століття: науково-практичне партнерство: матеріали міжн. симпозіуму, м. Київ, 6 червня 2019 р. Київ: НАКККіМ, 2019. Сс. 67-68.

14. Плахов А. «Кинофестивали не вымрут. Они изменятся». URL: $\quad$ https://newizv.ru/interview/20-06-2018/andrey-plahovkinofestivali-ne-vymrut- oni-izmenyatsya

15. Роднянський О. Три вектори. Кіно-коло. 1997. № 1. Cc. 21-22.

16. Тыркин С. Президент Каннского кинофестиваля Жиль Жакоб: «Тарантино мне отказал, а братьев Коэнов я все же уломал». URL: https://www.crimea.kp.ru/daily/24071.4/309006/

17. Український кінопрорив.

URL:https://nlu.org.ua/storage/files/Infocentr/Tematich_ogliadi/2015 /2015_kino15.pdf

18. A Gentle Creature. Krotkaya. URL:

https:// www.europeanfilmawards. eu/en_EN/film/a-gentlecreature. 9360 


\title{
Галина Петровна ПОГРЕБНЯК, \\ доктор искусствоведения, доцент, Национальная академия руководящих кадров культуры и искусств, Киев, Украина, e-mail: galina.pogrebniak@gmail.com, ORCID: 0000-0002-8846-4939
}

\begin{abstract}
Аннотация. В статье рассматриваются международные кинофестивали, имеющие значительный социальноэкономический потенциал и являющиеся мощной составляющей культурной жизни. Показано, что приметой нынешних международных кинофестивалей является возобновление тенденции острого критического взгляда на мир, а также усиление авторского начала, отражает жизненный опыт, характер мировосприятия и мировоспроизведения режиссерапостановщика - создателя собственной киномодели. Обоснована способность ведения межкультурного диалога средствами авторского кино. Определяется место украинских авторских фильмов в международном фестивальном пространстве. Прослеживается процесс вхождения отечественного авторского кинематографа в международное фестивальное пространство с целью распространения информации о системных изменениях в законодательстве по поддержке киноиндустрии; манифестации специфической художественно-эстетической и морально-этической направленности украинского киноискусства; демонстрации уровня профессиональной подготовки кинематографистов; представления фильмовой продукции представителям международной дистрибьюции; налаживание кросс-связей; укрепление кинематографического имиджа Украины. Установлено, что награждение украинских кинематографистов призами престижных международных кинофестивалей свидетельствует о способности отечественных мастеров, утверждая национальные приоритеты и освещая значимые
\end{abstract}


общечеловеческие проблемы, общаться с международным сообществом на понятном кинематографическом языке.

Доказано, что успех украинских фильмов на международных кинофорумах демонстрирует востребованность отечественного авторского кино в современном культурном пространстве, постепенное формирование брендов «украинское кино», «украинское авторское кино», создание у потенциальных партнеров узнаваемого положительного образа Украины. Доказано, что значительный успех Фестивалей украинского кино в разных странах мира свидетельствует о том, что отечественные авторские фильмы выступают мощным каналом коммуникации, частью культурной дипломатии, действенным инструментом культурной политики Украины, способствуя созданию ее имиджа как кинематографической страны и интеграции в мировое культурное пространство.

Ключевые слова: автор-режиссер, авторский кинематограф, авторская режиссерская модель, интеллектуальное кино, кинофестиваль, кросс-культурные связи

\section{Galyna P. POGREBNIAK,}

DSc in Arts, Associate Professor,

National Academy of

Management of Culture and Arts,

Kyiv, Ukraine, e-mail: galina.pogrebniak@gmail.com,

ORCID: 0000-0002-8846-4939

\section{FUNCTIONING OF DIRECTING MODELS OF AUTHOR CINEMA IN THE CULTURAL AND ARTISTIC SPACE OF INTERNATIONAL FILM FESTIVALS}

Abstract. The article considers international film festivals, which have significant socio-economic potential and are a powerful component of cultural and artistic life. It is shown that the hallmark of current international film festivals is the resumption of the trend of sharp critical view of the world, as well as strengthening the author's 
principle, which reflects life experience, the nature of worldview and world reproduction of the director - creator of his own film model. The ability to conduct intercultural dialogue by means of auteur cinema is substantiated. The place of Ukrainian auteur films in the international festival space is determined. The process of entry of domestic auteur cinema into the international festival space is traced in order to disseminate information about systemic changes in the legislation on the support of the film industry; manifestations of specific artistic-aesthetic and moral-ethical orientation of Ukrainian cinematography; demonstrations of the level of professional training of cinematographers; presentation of film products to representatives of international distribution; establishing cross-cultural ties; strengthening the cinematic image of Ukraine. It has been established that awarding Ukrainian filmmakers with prizes at prestigious international film festivals testifies to the ability of domestic masters, affirming national priorities and highlighting important universal problems, to communicate with the international community in an understandable cinematic language.

It is proved that the success of Ukrainian films at international film forums demonstrates the demand for domestic auteur cinema in the modern cultural space, the gradual formation of brands "Ukrainian cinema", "Ukrainian auteur cinema", the creation of potential partners recognizable positive image of Ukraine. It is proved that the significant success of Ukrainian Film Festivals in different countries of the world shows that domestic films are a powerful channel of communication, a component of cultural diplomacy, an effective tool of cultural policy of Ukraine, contributing to its image as a cinematic country and integration into the world cultural space.

Key words: author-director, author's cinema, author's director's model, intellectual cinema, film festival, cross-cultural relations

\section{References:}

1. Aleksandr Rodnyanskij (2016): "Rabota prodyusera - ehto brak s avtoroM" [Alexander Rodnyanskiy: "The work of a producer 
is a marriage with an author"]. Available at: https://mediananny.com/raznoe/2300316/ [in Russian]

2. Volosheniuk, O. (2014). Kinoreprezentatsii Maidanu: reabilitatsiia fizychnykh realnostei [Film representations of the Maidan: rehabilitation of physical realities]. Available at: http://medialiteracy.org.ua/kinoreprezentatsiyi-majdanureabilitatsiya-fizychnyh-realnostej [in Ukrainian]

3. Hrabovych, I. (2018). Vse bude Donbas? [Everything will be Donbass?]. Available at: https://detector.media/kritika/article/141309/2018-09-27/ [in Ukrainian]

4. Dokumentalna strichka "Maidan" Serhiia Loznytsi vykhodyt v ukrainskyi prokat u lypni [Serhiy Loznytsia's documentary "Maidan" will be released in Ukraine in July]. Available at: https://www.tv.zt.ua/index.php/ru/302-dajdzhest-novostej-tv-rynka1-16-marta-284 [in Ukrainian]

5. Dolin, A. (2018). "DonbasS" Sergeya Loznicy: teatr voennykh dejstvij i absurda. Na Kannskom festivale pokazali fil'm o zhizni v DNR i LNR ["Donbass" by Sergei Loznitsa: theater of military operations and absurdity. A film about life in the DPR and LPR was shown at the Cannes Film Festival]. Available at: https://meduza.io/feature/2018/05/09/donbass-sergeya-loznitsy-teatrvoennyh-deystviy -i-absurda [in Russian]

6. Donbas - mistse, de rozpadaietsia rytual. Serhii Loznytsia pro svoiu novu kartynu i viinu na Skhodi [Donbass is a place where the ritual breaks down. Sergei Loznitsa about his new picture and the war in the East]. Available at: https://nv.ua/radio/forperspectiveshow/donbas-mistse-derozpadajetsja-ritual-serhij-loznitsja-pro-svoju-novu-kartinu-i-vijnuna-skhodi-2506960.html [in Ukrainian]

7. Zakon Ukrainy "Pro kinematohrafiiu" [Law of Ukraine 'On Cinematography"]. Available at: https://zakon.rada.gov.ua/laws/show/9/98-\%D0\%B2\% D1\%80\#Text [in Ukrainian]

8. Karlova, V.V. (2011). Kulturna polityka [Cultural policy]. Filosofiia: slovnyk-dovidnyk. Za red.: I. F. Nadolnoho, I. I. 
Pylypenka, V.H. Chernetsia. Kyiv: NAKKKiM, 203-204 [in Ukrainian]

9. Loznytsa, S. "Maidan": "Dumat, chto takoi fylm mozhet yzmenyt sytuatsyiu - ehto ylliuzyia [Maidan: "To think that such a film can change the situation is an illusion]. Available at: https://platfor.ma/magazine/text-sq/experience/sergei-loznitsa/ [in Russian]

10. "Majdan" Cergeya Loznicy: Kanny - Odessa - mir ["Maidan" by Sergei Loznitsa: Cannes - Odessa - the world]. Available at: http://www.mk.mk.ua/rubric/culture/2014/07/19/15703/ [in Russian]

11. Makarov, Yu. Tvoryty ukrainskyi brend [Create a Ukrainian brand]. Available at: https://tyzhden.ua/Publication/2505 [in Ukrainian]

12. Novikova, L. (2020). Politychnyi aspekt diialnosti mizhnarodnykh kinofestyvaliv [Political aspect of international film festivals]. Suchasni doslidzhennia v haluzi kultury i mystetstva: $z b$. materialiv V Mizhn. nauk.-praktych. konf., 30.04.2020. Kyiv, 97-99 [in Ukrainian]

13. Ovcharuk, O. (2019). Kulturna dyplomatiia: teoretychnyi ta prykladnyi aspekt [Cultural diplomacy: theoretical and applied aspect]. Kulturni ta mystetski studii $\mathrm{KhKhI}$ stolittia: naukovopraktychne partnerstvo: materialy mizhn. sympoziumu, Kyiv, 6 chervnia 2019. Kyiv: NAKKKiM, 67-68 [in Ukrainian]

14. Plahov, A. "Kinofestivali ne vymrut. Oni izmenyatsya" ["Film festivals will not die out. They will change"]. Available at: https://newizv.ru/interview/20-06-2018/andrey-plahov-kinofestivaline-vymrut-oni-izmenyatsya [in Russian]

15. Rodnianskyi, O. (1997). Try vektory [Three vectors]. Kinokolo, 1, 21-22 [in Ukrainian]

16. Tyrkin, S. Prezident Kannskogo kinofestivalya Zhil' Zhakob: "Tarantino mne otkazal, a brat'ev Koehnov ya vse zhe ulomaL" [President of the Cannes Film Festival Gilles Jacob: "Tarantino refused me, but I still persuaded the Coen brothers"]. Available at: https://www.crimea.kp.ru/daily/24071.4/309006/ [in Russian] 
17. Ukrainskyi kinoproryv [Ukrainian film breakthrough]. Available at:

https://nlu.org.ua/storage/files/Infocentr/Tematich_ogliadi/2015/2015 kino15.pdf [in Ukrainian]

18. A Gentle Creature. Krotkaya. Available at:

https:// www.europeanfilmawards. eu/en_EN/film/a-gentlecreature.9360 [in English] 